\title{
Burnout Syndrome During the Covid-19 Pandemic among Visual Art Teachers in Ghana
}

\author{
${ }^{*}$ M Osei ${ }^{1}$, D Adom ${ }^{1}$, A Twene ${ }^{2}$, N Tetteh ${ }^{3}$ \\ ${ }^{1}$ Department of Educational Innovations in Science and Technology, Kwame Nkrumah University of Science and \\ Technology, Ghana \\ 2Department of Publishing Studies, Kwame Nkrumah University of Science and Technology, Ghana \\ 3Department of Industrial Art, Dr. Hilla Limann Technical University, Ghana
}

\begin{tabular}{l}
\hline Article Info \\
\hline Article history: \\
Received November 19, 2021 \\
Revised November 27, 2021 \\
Accepted December 6, 2021 \\
Available Online December 30, 2021 \\
\hline
\end{tabular}

Keywords:

Academic stress Burnout syndrome COVID-19

Stress coping mechanism

\begin{abstract}
This study sought to address burnout syndrome during the COVID19 global pandemic among visual art teachers in Ghana. The startling intricacies of COVID-19 burnout among Visual Art Teachers (VAT) in Ghana were discovered using an exploratory research approach. 112 participants were surveyed across Senior High Schools Visual Art Teachers in Ghana. Data were analysed using t-test, regression and analysis of variance test ( $\mathrm{F}$ test) to determine whether there were significant differences between the burnout levels and demographic factors. The findings revealed that, the only effects of the burnout that are statistically significant on gender are reduction in productivity or efficacy in teaching difference $(t=-4.41$, $p=0.00(p<0.05))$, sleep disorders $(t=-3.22, p=0.02(p<0.05))$, short temper $(\mathrm{t}=-2.84, \mathrm{p}=0.006(\mathrm{p}<0.05))$ and health consequences $(\mathrm{t}=3.36$, $\mathrm{p}=0.001(\mathrm{p}<0.05))$. The ANOVA was significant between burnout negative effect among education level $\mathrm{F}(3,108)=2.983, p=.035$. However, the ANOVA was insignificant between burnout causes, effects and preventive strategies scores and the ages of the teachers. The findings revealed that the majority of suggestions for burnout prevention falls under the category of personal changes. The study contends that though job responsibilities are high, the primary idea is that individuals have a larger role to play in preventing burnout.
\end{abstract}

\section{INTRODUCTION}

Academic activities in various educational institutions are fertile grounds for breeding stress among teachers and students (Edjah et al., 2020; Adom et al., 2020a). In its aggravated form, stress turns into burnout (Shailesh, 2018). Burnout is more prevalent in employment outlets where workers spend considerable time with their clients (Clutterbuck, 2009). Thus, it is no surprise to find the burnout syndrome among teachers because research tags the teaching profession as a high-stress job (Kyriacou, 2001; Hulya, 2014). The term burnout was first referenced in Graham Greene's novel titled 'A Burnt-Out Case' published in the early 1960s (Montero-Marin et al., 2016). However, Freudenberger, the American-German psychologist, is noted to be the celebrated name for the term 'burnout' in 1974. This is when he used it in describing the physical and emotional exhaustion faced by some young social workers he studied (Cluterbuck, 2009). Burnout has often been defined as a psychological response to chronic work-related stress (Shirom, 2003; Shailesh, 2018). It is a psychosocial condition that presents itself when a person is unable to cope with chronic stress (Montero-Marin et al., 2016). Burnout syndrome is a negative subjective experience with negative perceptions and behaviours evident after prolonged exposure to 
chronic stress (Ahola et al., 2010; Khamisa et al., 2017; UNESCO, 2020a). There has been a resurgent interest in burnout studies recently by scholars because of its negative effects on professions related to human services such as teaching (Hulya, 2014; Gorji, 2011).

The causes of burnout syndrome are multifaceted, though they are all forms of stressors (Shailesh, 2018). Among teachers, working for long hours due to high workloads, emotional exhaustion, pressure from educational administrators, role ambiguity, student-behaviour problems, lack of social support, lack of motivation and participatory decision-making, amongst many others, often result in burnout (Kyriacou, 2001; Zhang \& Sapp, 2007; Stoeber \& Rennert, 2008). The main causes of burnout syndrome in academic institutions are always associated with the challenges in the delivery of teaching and learning activities (Cruz \& Abellan, 2015). This drastically reduces the productivity or efficacy of teachers driven by a lack of enthusiasm (Rothmann et al., 2006; Najimi et al., 2014). Burnout syndrome develops gradually among teachers as they battle with ineffective stress management strategies (Schaufeli et al., 2009). Hamre and Pianta (2004) note that teachers affected by the burnout syndrome demonstrate less empathy and intolerance toward their students in the dispensation of classroom teaching and learning. There is also noticeable feelings of inadequacy and job dissatisfaction amongst teachers experiencing burnout syndrome (Kumari \& De Alwis, 2015; Khamisa et al., 2017). Such teachers are subject to physical, emotional and mental health disorders (Jennings, 2008; Idris, 2011; Young et al., 2013; Montero-Marin et al., 2016; Gorji, 2011). A teacher or educator who is undergoing burnout has low morale, low self-esteem, and is physically exhausted (Brown \& Roloff, 2011). Depression, musculoskeletal pain, cardiovascular diseases, and type 2 diabetes are all possible burnout health challenges faced by teachers. Other negative effects of burnout among teachers include sleeping disorders, strained relations with family and friends as well as short temperaments (García-Izquierdo \& R1'os-R1'squez, 2012).

Studies on burnout syndrome among teachers merit scholarly attention as it greatly affects the expected learning outcomes of students (Hulya, 2014; Khan et al., 2013; Veena \& Shailaja, 2016; Adom et al., 2020b). This has become even more necessary due to the unparalleled disruption of the foundations of education as a result of the recent COVID-19 global pandemic that forced the suspension of the West African Secondary School Certificate Examination (WASSCE) on March 20, 2020. Though recently ended, the WASSCE saw frantic preparations by teachers to put their candidates in the mode of the examination a couple of months ago when these final year students were called back into school amidst a lot of uncertainties. Teachers were thus under a lot of pressure to prepare students to be able to sit for these examinations, visual art teachers inclusive. Based on this backdrop, the main purpose of the study was to investigate the causes, effects and preventive strategies of the COVID-19 burnout syndrome on Visual Art teachers in Ghana. Also, it was to determine whether there was a significant negative effect of the COVID-19 burnout on the socio-demographic factors such as gender, age and educational levels of Visual Art Teachers. 


\section{Conceptual Framework}

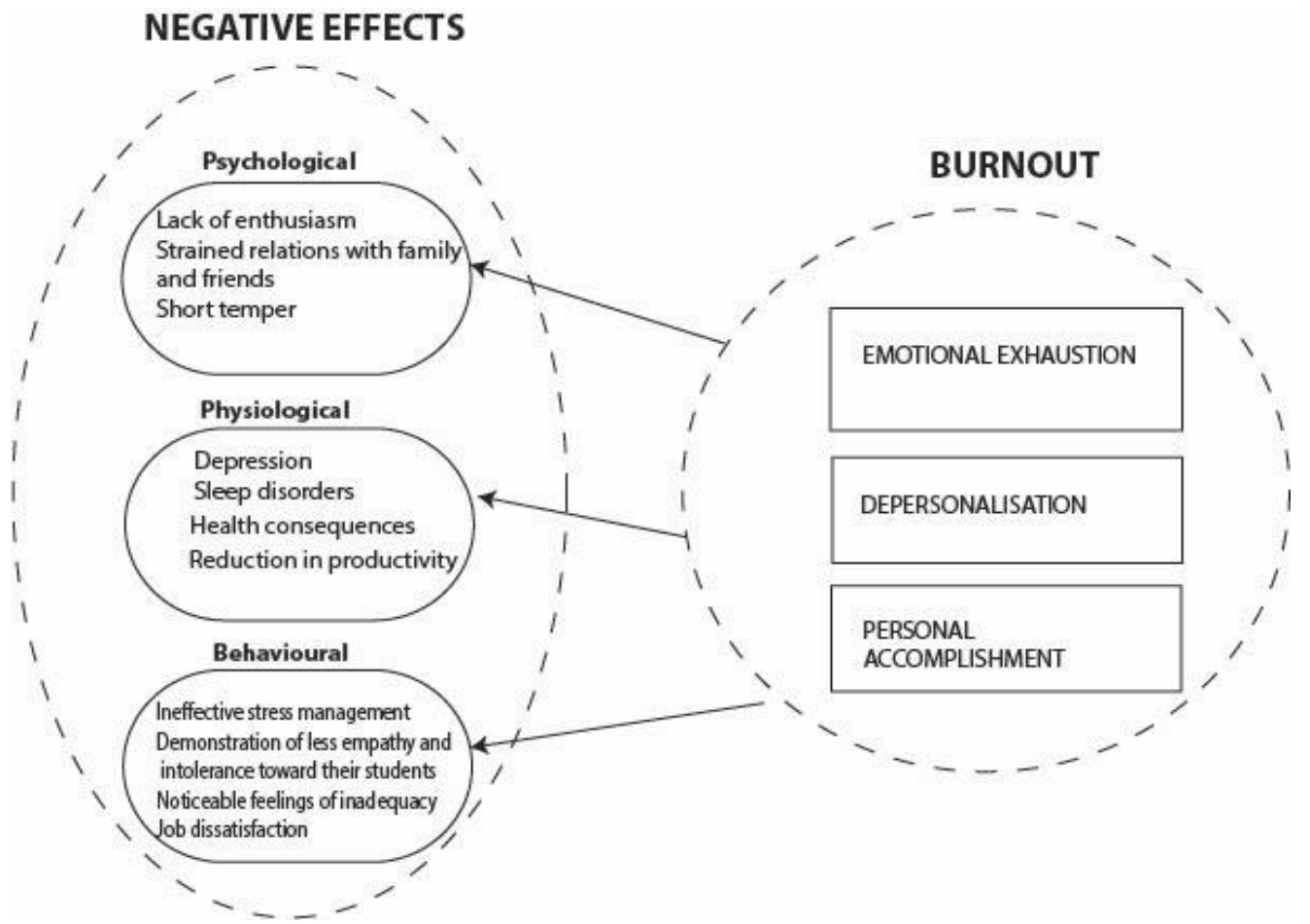

Figure 1. Adapted from the general model of burnout. Source: Maslach et al. (1996)

Job burnout study began in the human services sector in an attempt to describe the syndrome that afflicted the overworked, fatigued, and distant worker who was once driven and involved. Although there is some variation in burnout definitions, Maslach et al. (1996) conceptual and operational definition is the most generally used and recognized. Maslach et al. (1996) concept of job burnout posits a three-dimensional construct consisting of emotional exhaustion, depersonalization, and personal accomplishment. Burnout's central characteristic is emotional exhaustion, which is defined as a sense of being emptied as a result of long-term job stress. Emotional exhaustion causes the worker to pull away from clients, becoming cynical and disconnected. Depersonalization is the insensitivity to people receiving services and inappropriate behaviour toward others, regardless of their distinctions. Personal accomplishment, the third dimension, refers to sentiments of ineffectiveness at work, regardless of effort.

The following research question guides this study, which focuses on studies exploring the significant differences between job burnout and teachers well-being: Are there any significant negative effects of the COVID-19 burnout on gender (Visual Art Teachers)?; Are there any significant difference between burnout causes, effects and preventive strategies scores and the ages of Visual Art Teachers (VAT); To what extent did Visual Art Teachers (VAT) burnout causes, negative effect and preventive strategy vary depending on sociodemographic factors such as education level. (see Figure 1)? The negative effects of the COVID-19 burnout were categorised into three domains: Psychological, Physiological and Behavioural. The World Health Organization's comprehensive definition of health and well-being, which defines health as a state of total mental, bodily, and social welfare, guides this study's multi-domain approach (World Health Organization, 1948) - (1) Psychological well-being, (2) physiological well-being, and (3) behavioural well-being were the three well-being domains examined. Figure 1 indicated that the three categories of burnout (emotional exhaustion, depersonalisation and personal accomplishment give rise to these negative effects. 


\section{RESEARCH METHOD}

An exploratory research design was deemed to appropriate to discover the striking complexities of COVID-19 burnout among Visual Art Teachers (VAT) in Ghana. Exploratory research is conducted when enough is not known about a phenomenon and a problem that has not been clearly defined (Saunders et al., 2017). It does not plan to address the research questions in a final and definitive way, but rather discusses the research subject with different degrees of profundity. Therefore, it aims at addressing new issues that have not been investigated before. The study also employed a quantitative method through the use of questionnaire. On the other hand, the researchers would objectively use a quantitative approach to summarize the problem by using fixed numbers.

To provide insight into COVID-19 burnout among Visual Art Teachers, a convenience sampling technique $(\mathrm{N}=112)$ was used to recruit Senior High Visual Arts teachers in Ghana specifically Ashanti Region to complete the hard copy questionnaire during the wake of the COVID-19 pandemic. To participate, a teacher had to teach Visual Arts in Ashanti Region. The questionnaire included three different scales adopted and modified from (Maslach et al., 1996). The first scale included was the COVID-19 causative scale (12 items), the second scale included negative effects (12 items) and the last scale included the preventive strategies (16 items). A fivepoint Likert scale ranging from strongly disagree (1) to strongly agree (5) was used to measure the three different scales. An example question of the causative scale included, "high workloads due to class size." An example question of negative effects included, "challenges in the delivery of the teaching and learning activities" Lastly, an example question of preventive strategies included "training on self-control and stress management". In the study, t-test, regression and analysis of variance test (F-test) were used for the analysis of the data. A t-test was used to determine whether there were significant differences between both the burnout levels and the classroom management attitudes and beliefs of male and female teachers. Furthermore, the data were analyzed using ANOVA to find out whether there were significant differences among different categories of the variables under study (age, gender, and education level). Again, the data were analysed using regression to test the impact of burnout on Visual Art Teachers (VAT).

\section{RESULTS AND DISCUSSION}

Table 1 Reliability Statistics

A Cronbach's Alpha was used to prove the reliability and how consistent will be of the data collected. The results gave a good coefficient alpha of 0.822 .

Table 1. Gender distribution.

\begin{tabular}{llrr}
\hline & & Obs & Percent \\
\hline & Female & 21 & 18.8 \\
& Male & 90 & 80.4 \\
& Total & 111 & 99.1 \\
Total & & 112 & 100 \\
\hline
\end{tabular}

Table 1 , it shows that out of 112 respondents surveyed $80.4 \%$ of the respondents were male while $18.8 \%$ of the respondents were female.

Table 2. Educational qualification.

\begin{tabular}{llrr}
\hline & Obs & Percent \\
\hline Valid & Diploma & 6 & 5.4 \\
& 1st Degree & 82 & 73.2 \\
& Master's Degree & 20 & 17.9 \\
& PhD & 4 & 3.6 \\
& Total & 112 & 100 \\
\hline
\end{tabular}

Table 2 indicates that the majority of the respondents' educational qualification is 1 st degree representing 73.2\% and the qualification is Doctor in Philosophy representing 3.6\%. 
Table 3. Age distribution.

\begin{tabular}{lrrrr}
\hline & M & SD & Obs & Percent \\
\hline & $20-30$ & & 33 & 29.5 \\
& $31-40$ & & 53 & 47.3 \\
& $41-50$ & & 20 & 17.9 \\
& $51-60$ & & 4 & 3.6 \\
& Total & & 110 & 98.2 \\
Total & & & & 112 \\
\hline
\end{tabular}

Data from Table 3 suggests, a higher number of respondents which is 53(47.3\%), took part in the study were within the ages of 31-40 years and the least age group was 51-60 years representing $4(3.6 \%)$. The average age is $(\mathrm{M}=1.95, \mathrm{SD}=.794)$.

Table 4. Marital status.

\begin{tabular}{llrr}
\hline & & Obs & Percent \\
\hline Valid & Married & 70 & 63.6 \\
& Single & 40 & 36.4 \\
& Total & 110 & 100 \\
Total & & 112 & \\
\hline
\end{tabular}

Table 4 shows the majority of the respondents who took part in the study is married representing $63.6 \%$ and the remaining $36.4 \%$ is single.

Table 5. Subject distribution according to teachers.

\begin{tabular}{|c|c|c|c|}
\hline & & Teachers & Percent \\
\hline \multirow[t]{8}{*}{ Valid } & G.K.A & 33 & 29.5 \\
\hline & Textiles & 9 & 8 \\
\hline & G.K.A./Picture Making & 12 & 10.7 \\
\hline & Sculpture & 8 & 7.1 \\
\hline & Leather Work & 8 & 7.1 \\
\hline & Graphic Design & 25 & 22.3 \\
\hline & Picture Making & 7 & 6.3 \\
\hline & G.K.A/ Ceramics & 6 & 5.4 \\
\hline Total & & 112 & 100 \\
\hline
\end{tabular}

From Table 5, most of the respondents who participated in the survey were teachers of General Knowledge in Art (G.K.A.) representing 29.5\%, followed by Graphic Design teachers, representing $22.3 \%$ and the least participated participants were teachers teaching both G.K.A and Ceramics, representing $5.4 \%$.

Table 6. School distribution.

\begin{tabular}{|c|c|c|c|}
\hline \multicolumn{2}{|c|}{ Names of Participated Senior High Schools } & Number of Visual Art Teachers & Percent \\
\hline \multirow{12}{*}{ Valid } & Prempeh College & 4 & 3.6 \\
\hline & St. Louis & 5 & 4.5 \\
\hline & KSTS & 18 & 16.1 \\
\hline & Pakoso Community Day SHS & 8 & 7.1 \\
\hline & SDA SHS Bekwai & 14 & 12.5 \\
\hline & Kofi Agyei SHS & 9 & 8 \\
\hline & Serwaa Nyarko SHS & 6 & 5.4 \\
\hline & Ejisuman & 15 & 13.4 \\
\hline & ESTS & 2 & 1.8 \\
\hline & KNUST SHS & 6 & 5.4 \\
\hline & Adventist Senior High Kumasi & 3 & 2.7 \\
\hline & Kumasi Academy & 9 & 8 \\
\hline Total & & 112 & 100 \\
\hline
\end{tabular}


Table 6 indicates the number of Senior High Schools and Visual Arts teachers surveyed for this study.

Table 7. Causative, effects and preventive strategies

\begin{tabular}{|c|c|c|c|c|}
\hline Variable & Obs & Mode & $\mathbf{M}$ & SD \\
\hline \multicolumn{5}{|l|}{$\begin{array}{l}\text { CAUSATIVE AGENTS OF THE COVID-19 } \\
\text { BURNOUT }\end{array}$} \\
\hline 1. High workloads due to class size & 112 & Agree & 3.313 & 1.389 \\
\hline $\begin{array}{l}\text { 2. Emotional exhaustion as a result of } \\
\text { COVID-19 health concern }\end{array}$ & 112 & Agree & 3.473 & 1.185 \\
\hline 3. Financial problems & 112 & Agree & 3.321 & 1.092 \\
\hline 4. Fear or Uncertainty of the future & 112 & Neutral & 3.607 & 1.11 \\
\hline $\begin{array}{l}\text { 5. Pressure from educational } \\
\text { administrators }\end{array}$ & 106 & Agree & 3.377 & 1.238 \\
\hline 6. Role ambiguity & 110 & Neutral & 2.973 & 0.999 \\
\hline 7. Student-behaviour problems & 108 & Agree & 3.574 & 1.129 \\
\hline 8. Lack of social support & 110 & Agree & 3.782 & 1.144 \\
\hline 9. Lack of motivation & 104 & Agree & 3.637 & 1.215 \\
\hline 10. Lack of participatory decision-making & 111 & Agree & 3.279 & 1.192 \\
\hline $\begin{array}{l}\text { 11. Inability to engage in cultural events } \\
\text { such as funeral etc. }\end{array}$ & 110 & Neutral & 3.536 & 1.217 \\
\hline $\begin{array}{l}\text { 12. Inability to associate with friends, and } \\
\text { family as a result of the COVID-19 lockdown }\end{array}$ & 112 & Neutral & 3.455 & 1.177 \\
\hline $\begin{array}{l}\text { OVERALL MEAN } \\
\text { NEGATIVE EFFECTS OF THE COVID-19 } \\
\text { BURNOUT }\end{array}$ & & & 3.443 & \\
\hline $\begin{array}{l}\text { 1. Challenges in the delivery of the } \\
\text { teaching and learning activities }\end{array}$ & 108 & Agree & 3.315 & 1.22 \\
\hline $\begin{array}{l}\text { 2. Reduction in productivity or efficacy in } \\
\text { teaching }\end{array}$ & 112 & Neutral & 3.179 & 0.97 \\
\hline 3. Lack of enthusiasm & 112 & Neutral & 3.179 & 0.942 \\
\hline $\begin{array}{l}\text { 4. Ineffective stress management } \\
\text { strategies }\end{array}$ & 112 & Neutral & 3.214 & 1.118 \\
\hline $\begin{array}{l}\text { 5. Demonstration of less empathy and } \\
\text { intolerance toward their students }\end{array}$ & 110 & Neutral & 2.709 & 1.061 \\
\hline 6. Noticeable feelings of inadequacy & 112 & Neutral & 3.08 & 1.00574 \\
\hline 7. Job dissatisfaction & 112 & Neutral & 2.759 & 1.05 \\
\hline 8. Depression & 110 & Neutral & 2.964 & 1.091 \\
\hline 9. Sleep disorders & 112 & Neutral & 2.991 & 1.095 \\
\hline $\begin{array}{l}\text { 10. Strained relations with family and } \\
\text { friends }\end{array}$ & 112 & Neutral & 3.232 & 1.082 \\
\hline 11. Short temper & 112 & Neutral & 2.563 & 1.02 \\
\hline 12. Health consequences & 111 & Neutral & 2.775 & 1.248 \\
\hline OVERALL MEAN & & & 2.997 & \\
\hline $\begin{array}{l}\text { COVID-19 BURNOUT PREVENTIVE } \\
\text { STRATEGIES }\end{array}$ & & & & \\
\hline $\begin{array}{l}\text { 1. Training on self-control and stress } \\
\text { management }\end{array}$ & 112 & Agree & 3.821 & 0.951 \\
\hline $\begin{array}{l}\text { 2. Taking time off to think, reflect, } \\
\text { meditate and pray }\end{array}$ & 110 & Agree & 3.809 & 0.943 \\
\hline $\begin{array}{l}\text { 3. Taking time off their busy schedules to } \\
\text { relax or sleep }\end{array}$ & 112 & Agree & 3.676 & 1.18 \\
\hline $\begin{array}{l}\text { 4. Engaging in fun activities (game movie, } \\
\text { concert) }\end{array}$ & 112 & Agree & 3.429 & 1.271 \\
\hline 5. Going for vacation & 112 & Agree & 3.821 & 0.97 \\
\hline $\begin{array}{l}\text { 6. Aerobic exercises/muscles } \\
\text { relaxation/breathing exercises }\end{array}$ & 112 & Agree & 3.607 & 1.188 \\
\hline
\end{tabular}




\begin{tabular}{|c|c|c|c|c|}
\hline $\begin{array}{l}\text { 7. Sharing feelings with friends and } \\
\text { family }\end{array}$ & 110 & Agree & 3.6 & 1.094 \\
\hline 8. Having a healthy home life & 111 & Agree & 3.846 & 1.138 \\
\hline 9. Eating a healthy balanced meal & 110 & Agree & 4.073 & 0.945 \\
\hline $\begin{array}{l}\text { 10. School administration consulting } \\
\text { teachers on curriculum development }\end{array}$ & 110 & Agree & 3.827 & 1.132 \\
\hline $\begin{array}{l}\text { 11. Provision of adequate instructional } \\
\text { facilities for teaching and practical activities }\end{array}$ & 108 & Agree & 4 & 1.005 \\
\hline $\begin{array}{l}\text { 12. Giving teachers clear job descriptions } \\
\text { and expectations }\end{array}$ & 112 & Agree & 3.938 & 0.952 \\
\hline $\begin{array}{l}\text { 13. Offering training programmes targeted } \\
\text { at the professional growth of teachers }\end{array}$ & 110 & Agree & 3.882 & 1.147 \\
\hline $\begin{array}{l}\text { 14. Organizing health promotion and } \\
\text { awareness programs for teaching staff }\end{array}$ & 112 & Agree & 3.938 & 1.157 \\
\hline $\begin{array}{l}\text { 15. Setting short- and long-term realistic } \\
\text { goals }\end{array}$ & 110 & Agree & 3.891 & 1.026 \\
\hline $\begin{array}{l}\text { 16. Setting limits on excessive or } \\
\text { inappropriate work demands }\end{array}$ & 108 & Agree & 3.852 & 0.975 \\
\hline OVERALL MEAN & & & 3.813 & \\
\hline
\end{tabular}

Note: The five-point Likert scale ranges from Strongly Disagree =1, Disagree = 2, Neutral =3, Agree = 4, Strongly Agree= 5

Table 7 indicates the analysis of the causative agents, effects and preventive strategies of the COVID-19 burnout among Visual Art Teachers (VAT). With regards to the causes of the COVID19 burnout, the responses to the first statement shows that high workloads due to class size are one of the causative agents of COVID-19 burnout (Mode = Agree, $\mathrm{M}=3.313, \mathrm{SD}=1.389$ ). The respondents also agree that emotional exhaustion as a result of COVID-19 health concern is a causative agent $($ Mode $=$ Agree $\mathrm{M}=3.473, \mathrm{SD}=1.185$ ). Contrariwise, the respondents were neutral about these statements as causative agents of the COVID-19 burnout among visual arts teachers: "financial problems, fear or uncertainty of the future, role ambiguity, lack of participatory decision-making and inability to engage in cultural events such as funeral". Owing to this, the overall mean (Mode $=4, M=3.443$ ) suggests the majority of the respondents were in agreement with the 12 statements (8 out of 12 statements indicate agreement) used to test as causative agents of the COVID-19 burnout among visual arts teachers in Ashanti Region specifically Senior High Schools.

Concerning the negative effects of the COVID-19 burnout on Visual Arts teachers, the respondents were neutral to the majority of the statements. For instance, out of 12 statements, only one shows positive agreement to the negative effect of the COVID-19 burnout on them that is "Challenges in the delivery of the teaching and learning activities (Mode = Agree M = 3.315, SD = 1.220). The overall mean and mode also indicate neutrality among the respondents (Mode $=$ Neutral, $M=2.997)$. Regarding the preventive strategies to curb the COVID-19 burnout, the overall sampled participants representing 100\% (112) agreed that the 16 listed statements in table 4.8 could be used as a strategy to control the COVID-19 burnout. The overall mean and mode suggest a positive agreement (Mode $=$ Agree, $\mathrm{M}=3.813$ ). 
(R1) Are there any significant negative effects of the COVID-19 burnout on gender (Visual Art Teachers)?

Table 8. Multiple regression analysis on the effect of covid-19 burnout on VAT

\begin{tabular}{lcccccc} 
Equation & Obs & Parms & RMSE & "R-sq" & F & P \\
\hline SEX & 106 & 12 & .3457316 & 0.3328 & 4.26196 & 0.0000
\end{tabular}

\begin{tabular}{r|rrrrrr}
\hline SEX & Coef. & Std. Err. & $t$ & P $>|t|$ & [95\% Conf. Interval] \\
\hline reduction & -.181413 & .040236 & -4.51 & 0.000 & -.2613024 & -.1015235 \\
enthusiasm & .075653 & .0555782 & 1.36 & 0.177 & -.0346988 & .1860047 \\
Ineffective & -.0178913 & .0465554 & -0.38 & 0.702 & -.1103282 & .0745456 \\
Demonstration & .0104773 & .0407204 & 0.26 & 0.798 & -.0703741 & .0913286 \\
Noticeable & .0318595 & .0451367 & 0.71 & 0.482 & -.0577605 & .1214794 \\
Job & .0745642 & .0500429 & 1.49 & 0.140 & -.0247972 & .1739256 \\
Depression & -.0519436 & .0391799 & -1.33 & 0.188 & -.1297363 & .025849 \\
Sleep & -.1443254 & .0448175 & -3.22 & 0.002 & -.2333117 & -.0553392 \\
Strained & .0598537 & .0478056 & 1.25 & 0.214 & -.0350655 & .1547729 \\
short & -.1216648 & .0428757 & -2.84 & 0.006 & -.2067955 & -.0365342 \\
Health & .1344925 & .0399829 & 3.36 & 0.001 & .0551055 & .2138795 \\
cons & 2.185539 & .1821568 & 12.00 & 0.000 & 1.823862 & 2.547216 \\
\hline
\end{tabular}

The F-test analysis in table 4.8 shows that there is an equal variance between the two groups namely sex and the effects $((\mathrm{F}$ test; $\mathrm{F}=4.26196 \mathrm{p}=0.000(\mathrm{p}<0.05))$. Again, the only effects of the burnout that are statistically significant are reduction in productivity or efficacy in teaching difference $(t=-4.41, p=0.00(p<0.05))$, sleep disorders $(t=-3.22, p=0.02(p<0.05))$, short temper $(t=$ $-2.84, p=0.006(p<0.05))$ and health consequences $(t=3.36, p=0.001(p<0.05))$. The rest is statistically insignificant (Table 4.9). However, 33\% approximately of the variance is connected to the effects of COVID-19 burnout among VAT. This variation is too small leaving several differences unexplained. It could also be deduced that only reduction in productivity, as well as sleep disorders, short temper and health consequences, are predictors of the negative effects of the COVID-19 burnout among VAT. The value for the R-squared is 0.3328 . This implies that in this model only approximately $33 \%$ of the variance accounts for the negative effect of burnout among teachers.

(R2) Are there any significant difference between burnout causes, effects and preventive strategies scores and the ages of Visual Art Teachers (VAT)

A one-way analysis of variance was conducted to evaluate the difference between burnout scores and the ages of Visual Art Teachers (VAT). The independent variable is the age of the Visual Art Teachers and the dependent variable is burnout scores. The independent variable has 4 levels: 20-30, 31-40, 41-50, and 51-60 while the dependent variable has 3 levels: causes, negative effects and preventive strategies. The ANOVA was insignificant COVID-19 burnout causes scores and ages of VAT $F(3,106)=2.240, p=.087$. The variance estimates between the subject scores (ages) are 1.014 and within the subject scores (ages) is .0.451. This implies that the population variance is nearly 2.2 times greater than within the subject scores (ages) that are being accounted for. The value for the R-squared is 0.060 . This shows that, in this model, only approximately $6 \%$ of the variance accounts for burnout causes scores leaving several differences unexplained. Also, there was not a statistically significant difference between burnout negative scores and age $F$ (3, $106)=.647, p=.587$. The value R-squared is .018. Again, the ANOVA was insignificant between burnout preventive strategy scores and ages $F(3,106)=2.221, p=.0 .09$ and the value for the Rsquared is .059 .

(R3) To what extent did Visual Art Teachers (VAT) burnout causes, negative effect and preventive strategy vary depending on socio-demographic factors such as (R3a) education level? 
ANOVA was conducted to assess the difference between burnout causes, negative effects and preventive strategy and education level. The independent variable is education level and the dependent variable is burnout. The independent variable has 4 levels: Diploma, 1st Degree, Master's Degree, and Doctorate Degree and the dependent variable has 3 levels: causes, negative effects and preventive strategy. The ANOVA was insignificant between education level and burnout causes $F(3,108)=1.735, p=.164$. The variance estimates between the subject scores (education level) are .783 and within the education level is .452. This means that the population variance is approximately 2 times greater than within the subject experience (education level) that is being accounted for. The value for the R-squared is .046. Also, there was not a statistically significant difference between preventive strategy among education level $F(3,108)=.661, p=$ .578. The value for R-squared is .018. However, the ANOVA was significant between burnout negative effect among education level $\mathrm{F}(3,108)=2.983, p=.035$. The variance estimates between the subject scores (education level) are 1.783 and within the group of education level is .352. The value for the R-squared is .077 . This shows that, in this model, only approximately $8 \%$ of the variance accounts for burnout negative effects leaving several differences unexplained.

Since the overall F-test was only statistically significant between burnout negative effect score and education of levels of VAT, post hoc multiple comparisons were conducted to determine the pairwise difference among the means of the four groups of education levels. The procedure adopted for these multiple comparisons is Tukey. The Post-hoc t-tests indicated that there was a significant difference in the means between teachers with lower and high education levels and burnout negative effects $(p=0.041)$ as well as between low and high education levels $(p=0.047)$. However, low and middle educated VAT did not indicate the tendency of burnout negative effects $(p=.708)$. Again, there was not a significant difference in the means between VAT with middle and high education levels $(p=.205)$. It could be deduced that VAT with lower, low and high education levels was highly affected during the COVID-19 burnout. The $95 \%$ confidence intervals for the pairwise differences are reported in Table 9.

Table 9. Post hoc test

\begin{tabular}{|c|c|c|c|c|c|c|}
\hline \multirow{2}{*}{$\begin{array}{l}\text { Dependent Variable: } \\
\text { Tukey HSD }\end{array}$} & \multicolumn{6}{|l|}{ Negative Effect } \\
\hline & & & & & & \\
\hline \multirow[t]{3}{*}{ (I) Educational Qualifi } & tion & $\begin{array}{c}\text { Mean } \\
\text { Difference (I-J) }\end{array}$ & $\begin{array}{l}\text { Std. } \\
\text { Error }\end{array}$ & Sig. & $\begin{array}{l}95 \% \mathrm{Co} \\
\text { Inte }\end{array}$ & dence \\
\hline & & & & & Lower & Upper \\
\hline & & & & & Bound & Bound \\
\hline \multirow[t]{3}{*}{ Diploma } & 1st Degree & -.2289 & .25077 & .798 & -.8833 & .4255 \\
\hline & Master's Degree & -.3872 & .27600 & .500 & -1.1075 & .3330 \\
\hline & $\mathrm{PhD}$ & $-1.0278^{*}$ & .38275 & .041 & -2.0266 & -.0290 \\
\hline \multirow[t]{3}{*}{ 1st Degree } & Diploma & .2289 & .25077 & .798 & -.4255 & .8833 \\
\hline & Master's Degree & -.1583 & .14788 & .708 & -.5442 & .2275 \\
\hline & $\mathrm{PhD}$ & $-.7989^{*}$ & .30362 & .047 & -1.5912 & -.0066 \\
\hline \multirow[t]{3}{*}{ Master's Degree } & Diploma & .3872 & .27600 & .500 & -.3330 & 1.1075 \\
\hline & 1st Degree & .1583 & .14788 & .708 & -.2275 & .5442 \\
\hline & $\mathrm{PhD}$ & -.6405 & .32477 & .205 & -1.4880 & .2070 \\
\hline \multirow{3}{*}{ PhD } & Diploma & $1.0278^{*}$ & .38275 & .041 & .0290 & 2.0266 \\
\hline & 1st Degree & $.7989^{*}$ & .30362 & .047 & .0066 & 1.5912 \\
\hline & Master's Degree & .6405 & .32477 & .205 & -.2070 & 1.4880 \\
\hline \multicolumn{7}{|c|}{$\begin{array}{l}\text { Based on observed means. } \\
\text { The error term is Mean Square (Error) }=.352 \text {. }\end{array}$} \\
\hline
\end{tabular}

*. The mean difference is significant at the .05 level.

Note: Lower $=$ Diploma, low $=1^{\text {st }}$ Degree, Middle $=$ Master Degree, High $=\mathrm{PhD}$

The study aims to examine the COVID-19 burnout among Visual Arts Teachers (VAT) in Ghana such as the causes, effects and preventive strategies put in place in order to curb the burnout. 


\section{Causative Agents of the COVID-19 Burnout}

The findings reveal that most of the visual art teachers agree that the causes of the COVID-19 burnout affected their profession and life during the pandemic. This finding is congruent with recent studies in an Italian and Chilean population, which showed a significantly lower psychological wellbeing among people and individuals with health risk factors (Lizana et al., 2021; Pieh et al., 2020). Similar results have also been found in Austria, where women and young adults aged less than 35 years and the unemployed and the impoverished have problems with mental health due to an increase in depression and a decline in quality of life.

\section{Negative Effects of the COVID-19 Burnout}

With regards to the negative effect of the COVID-19 burnout, teachers' opinions were normally distributed. There was no clear indication that the COVID-19 burnout has affected their quality of life and their field of work. Although studies on the effect of COVID-19 burnout on teachers is scanty, the findings reveal that visual art teachers face challenges in the delivery of teaching and learning activities due to inadequate resources. This result is paralleled with the studies conducted by (Sokal et al., 2020). Owing to this, recent research has shown that teachers have been stressed to adjust (at record time) to conduct online classes during lock-down (Besser et al., 2020). This stress is typically accompanied by worry, sadness and sleep disturbance as a result of increased workload as a result of home education $(\mathrm{Ng}, 2007)$. Another recent Arab study has confirmed that this crisis has caused teachers to suffer problems that are often related to a pandemic situation, such as anxiety, depression, domestic violence, and divorce, all of which restrict their ability to teach properly (Al Lily et al., 2020). Moreover, prior research has demonstrated that working at home using ICT can produce emotions of strain, anxiety, weariness and decreased work satisfaction (Cuervo et al., 2018) and that these were the only facilities accessible for teachers during the pandemic.

The research findings also indicate that under-efficiency, lower flexibility as evaluated by attitudes to change, and more demand for work combined with lower resources are connected with teacher burnout in the pandemic situation. In addition to this, the multiple regression analysis reveals that there is an equal variance between the two groups namely sex and the effects but approximately $33 \%$ of the variance is connected to the effects of COVID-19 burnout among VAT. This variation is too small leaving several differences unexplained. Also, the findings of this study confirm that a high percentage of visual art teachers suffer symptoms of sleeping disorders, short temper, health disorders; which is statistically significant according to the multiple regression analysis. A plethora of studies confirm these findings of the negative effect of COVID19 burnout (Lizana et al., 2021; Besser et al., 2020; UNESCO, 2020b).

\section{COVID-19 Burnout Preventive Strategies}

Regarding the preventive strategies to curb the COVID-19 burnout, the overall sampled participants representing 100\% (112) agreed that the 16 listed statements in table 4.8 could be used as a strategy to control the COVID-19 burnout. The overall mean and mode suggest a positive agreement. In line with a recent study in Japan, mindfulness, counselling those at risk of burnout, and reducing workload have been proposed as measures to address the widespread burnout among workers given the unprecedented surge in COVID-19 cases (Correia \& Almeida, 2020). Also, psychological resilience has been highlighted as a protective factor against burnout (Di Monte et al., 2020). Although there are no simple answers to the prevention of burnout, it would be important to ensure shift efforts to prevent overwork and to provide support for mental health at a high level of policy to enhance efficiency. Taking time off busy schedules to relax is one of the preventive strategies to curb work burnout (Maslach \& Goldberg, 1998). According to the authors, there are different strategies to reduce high excitement and achieve a calm condition, from biofeedback, meditation and massages to hot baths. Some relaxation tactics are geared for the job, while others focus on relaxing when the workday is through (Hamberger \& Stone, 1983; Homer, 1985). A relaxed lifestyle also incorporates positive interests in non-work-related 
activities and hobbies and is therefore promoted as a technique to compensate for burnout stress (MacBride, 1983).

Healthy living at home and nutritious food are other preventive precaution that was considered by the VAT. The necessity of excellent health is so important that frequently it is not explained why it is anti-burnout (Slavin, 2019). The opposite viewpoint, however, was that, in addition to their intrinsic health benefits, such wellness programmes, only temporarily reduce burnout and do not avoid stress problems (Donatelle \& Hawkins, 1989). It is usually considered that a person is protected against burnout by good health and fitness. Therefore, most suggestions for burnout prevention contain diet and exercise advice in addition to the other measures (Leighton \& Roye, 1984; Lowenstein, 1991; Ross, 1993). In addition to this, one apparent preventive measure adopted by the visual art teachers in this study was setting short- and longterm realistic goals and limits on excessive or inappropriate work demand. Sometimes this takes the form of advocating a permanent reduction in hours worked per week (Homer, 1985). In other cases, the proposal is to deliberately slow down the pace of work once burnout begins to appear, rather than to shift into overdrive and work harder than ever (Lyall, 1989). However, there was no significant difference between preventive strategies and socio-demographic factors such as sex, age and education level of Visual Art Teachers.

\section{CONCLUSION}

The study's purpose was to find out the causes, effects and preventive strategies for COVID-19 burnout syndrome for Visual Art teachers in Ghana. Also, it was to determine whether there was a significant negative effect of the COVID-19 burnout on the socio-demographic factors such as gender, age and educational levels of Visual Art Teachers (VAT). The findings of this study revealed approximately $33 \%$ of the variance accounts for the negative effect of burnout among teachers. With regards to the preventive strategies, the overall mean and mode suggest a positive agreement. Nevertheless, the difference between preventive strategies and socio-demographic factors such as age and educational level of VAT was statistically insignificant. Contrariwise, there was a significant difference between burnout negative effects and different categories of education level.

Given how much more research is needed to fully comprehend the complexities of burnout causes and effects, it would be premature to assume that there is a definitive solution to this problem. However, as the risk of burnout spreads to other work contexts, the need to identify those answers is becoming increasingly essential. The majority of advice for burnout prevention falls under the area of person modification according to burnout. Although workplace demands are significant the basic concept is that teachers have a larger role in burnout prevention. This individualistic argument is based on a variety of assumptions. To begin with, the cause of burnout is usually attributed to the teacher rather than the workplace. Burnout is caused not just by a harsh working environment but also by the teacher's workaholic attitude toward this situation. Again, for institutional burnout to be curbed, the stakeholders in education precisely the Ghana Education Service (GES) and Ministry of Education (MOE) must establish counselling units in schools to help teachers who are stressed. The scope of the study is dictated by quantitative variables and the specific recommendations made by the researchers. However, this study did not adequately address all the variables to assess burnout syndrome during the COVID-19 pandemic; a qualitative study is therefore suggested to investigate the actual practice of teachers that causes burnout, to create a more complete picture of the causes and effects of the burnouts. Also, one particular subject which the researcher has not discussed in this study, but which is worth researching and which complements this study is the perspective of pupils or students on COVID-19 burnout due to large class size.

\section{ACKNOWLEDGEMENTS}

The authors would like to thank our research assistants, Lydia, Belinda, and Emmanuella for helping us with the collection of the data for the study. 


\section{REFERENCES}

Adom, D., Chukweure, J. \& Osei, M. (2020b). Review: Academic stress among faculty and student in higher institutions. Journal of Humanities and Social Sciences, 28(2), 1055-1064.

Adom, D., Essel, H. B., \& Chukwuere, J.E. (2020a). The state of academic stress in the Higher Institutions of Ghana: The way forward. Universal Journal of Educational Research, 8, 321-331.

Ahola, K., Väänänen, A., Koskinen, A., Kouvonen, A., \& Shirom, A. (2010). Burnout as a predictor of mortality among industrial employees: Ten-year prospective register-linkage study. Journal of Psychosomatic Research, 69, 51-57. https:// doi.org/10.1016/j.jpsychores.2010.01.002

Al-Lily, A. E. \& Al-Lily, M. (2020). The methodology of door-knocking: Saudi household surveys on socioeconomics and learning technologies. Cogent Social Sciences, 6(1), 1-12.

Besser, A., Lotem, S. \& Zeigler-Hill, V. (2020). Psychological stress and vocal symptoms among university professors in israel: implications of the shift to online synchronous teaching during the COVID-19 Pandemic. Journal of Voice Official, S0892-1997, 30190-30199. https://doi.org/10.1016/j.jvoice.2020.05.028

Brown, L. A.\& Roloff, M. E. (2011). Extra-Role Time, burnout, and commitment: The power of $\begin{array}{llll}\text { promises kept. Business Communication Quarterly, 74(4), 450-474. } & \text {. }\end{array}$ https:// doi.org/10.1177/1080569911424202

Clutterbuck, D. (2009). Coaching and mentoring in support of management development. In S. J. Armstrong \& C. V. Fukami (Eds). A SAGE handbook of management learning, education and development.

Correia, I. \& Almeida, A. E. (2020). Organizational justice, professional identification, empathy, and meaningful work during COVID-19 pandemic: Are they burnout protectors in physicians and nurses?. Frontiers in Psychology, 11, 566139.

Cruz, S. P. \& Abellan, M. V. (2015). Professional burnout, stress and job satisfaction of nursing staff at a university hospital. Revista Latino-Americana de Enfermagem, 23(3), 544-552. https://doi.org/10.1590/0104-1169.0284.2586

Cuervo, T. C., Orviz, N. M., Arce, S. G. \& Fernández, I. S. (2018). Technostress in communication and technology society: Scoping literature review from the web of science. Archivos Prevencion Riesgos Laborales, 18-25. https:// doi.org/10.12961/aprl.2018.21.1.04

Di Monte, C., Monaco, S., Mariani, R. \& Di Trani, M. (2020). From resilience to burnout: Psychological features of Italian general practitioners during covid-19 emergency. Frontiers in Psychology, 11, 567201.

Donatelle, R. J., \& Hawkins, M. J. (1989). Employee stress claims increasing implications for health promotion programming. American Journal of Health Promotion, 3, 19-25.

Edjah, K., Ankomah, F., Domey, E. \& Laryea, J. (2020). Stress and its impact on academic and social life of undergraduate University students in Ghana: A structural equation modeling approach. Open Education Studies, 2(1), 37-44. https://doi.org/10.1515/edu-2020-0100

García-Izquierdo, M. \& Ríos-Rísquez, M. I. (2012). The relationship between psychosocial job stress and burnout in emergency departments: an exploratory study. Nurs Outlook, 60(5), 3229. https:/ / doi.org/10.1016/j.outlook.2012.02.002

Gorji, M. (2011). The Effect of job burnout dimension on employee's performance. International Journal of Social Science and Humanity, 243-246.

Hamberger, L. K., \& Stone, G. V. (1983). Burnout prevention for human service professionals: Proposal for a systematic approach. Journal of Holistic Medicine, 5, 149-162. 
Hamre, B. K., \& Pianta, R. C. (2004). Self-reported depression in nonfamilial caregivers: prevalence and associations with caregiver behavior in child-care settings. Early Childhood Research Quarterly, 19(2), 297-318. https://doi.org/10.1016/j.ecresq.2004.04.006

Homer, J. B. (1985). Worker burnout: A dynamic model with implications for prevention and control. System Dynamics Review, I, 42-62.

Hülya, K. (2014). Ways to cope with teacher burnout factors in ELT classrooms. Procedia - Social and Behavioral Sciences, 116, 2741-2746. https:/ / doi.org/10.1016/j.sbspro.2014.01.647

Idris, M.K. (2011). Overtime effects of role stress on psychological strain among Malaysian public university academics. Psychology.

Jennings, B. (2008). Work Stress and burnout among nurses: Role of the work environment and working conditions. In: Hughes, R. G., Ed., Patient Safety and Quality: An Evidence-Based Handbook for Nurses, Agency for Healthcare Research and Quality. Rockville, 135-158.

Khamisa, N. \& Peltzer, K., Ilic, D. \& Oldenburg, B. (2017). Effect of personal and work stress on burnout, job satisfaction and general health of hospital nurses in South Africa. Health SA Gesondheid, 22, 252-258. https:// doi.org/10.1016/j.hsag.2016.10.001

Khan, M. J., Altaf, S. \& Kausar, H. (2013) Effect of perceived academic stress on students' performance. FWU Journal of Social Sciences, 7, 146.

Kumari, H., \& De Alwis, A. C. (2015). The nursing shortage impacton job outcome (The case in Sri Lanka). Journal of Competitiveness, 7(3), 75-94.

Kyriacou, C. (2001). Teacher Stress: Directions for future research. Educational Review, 53(1), 2735. https:// doi.org/10.1080/00131910120033628

Leighton, S. L., \& Roye, A. K. (1984). Prevention and self-care for professional burnout. Family $\mathcal{E}$ Community Health, 6, 44-56.

Lizana, P. A., Vega-Fernadez, G., Gomez-Bruton, A., Leyton, B., \& Lera, L. (2021). Impact of the covid-19 pandemic on teacher quality of life: A longitudinal study from before and during the health crisis. International Journal of Environmental Research and Public Health, 18(7). https://doi.org/10.3390/ijerph18073764

Lowenstein, L. (1991). Teacher stress leading to burnout-Its prevention and cure. Education Today, $41,12-16$.

Lyall, A. (1989). The prevention and treatment of professional burnout. Loss, Grief, \& Care, 3, 2732.

MacBride, A. (1983). Burnout: Possible? Probable? Preventable? Canada's mental health, 31, 2-3, 8.

Maslach, C., \& Goldberg, J. (1998). Prevention of burnout: New perspectives. Applied and Preventive Psychology, 7(1), 63-74. https://doi.org/10.1016/S0962-1849(98)80022-X

Maslach, C., Jackson, S. E., \& Leiter, M. P. (1996). Maslach Burnout Inventory. https://www.psychaanalyse.com

Montero-Marin, J., Prado-Abril, J., Demarzo, M., Md, M. \& Garcia-Campayo, J. (2016). Burnout subtypes and their clinical implications: A theoretical proposal for specific therapeutic approaches. Revista de Psicopatología y Psicología Clínica, 21, 231-242.

Najimi, A., Goudarzi, A. M., \& Sharifirad, G. (2012). Causes of job stress in nurses. A crosssectional study. Iranian journal of nursing and midwifery research, 17, 301-305.

$\mathrm{Ng}$, K. C. (2007). Replacing face-to-face tutorials by synchronous online technologies: Challenges and pedagogical implications. International Review of Research in Open and Distributed Learning, 8, 335. 
Pieh, C., Budimir, S. \& Probst, T. (2020). The effect of age, gender, income, work, and physical activity on mental health during coronavirus disease (COVID-19) lockdown in Austria. Journal of psychosomatic research, 136, 110186.

Ross, E. (1993). Preventing burnout among social workers employed in the field of AIDS/HIV. Social work in health care, 18(2), 91-108. https:// doi.org/10.1300/J010v18n02_06

Rothmann, S., Mostert, K., \& Strydom, M. (2006). A psychometric evaluation of the job demands resources scale in South Africa. South African Journal of Industrial Psychology, 32(4), 76-86.

Saunders, A., Green, R. \& Cross, M. (2017). Making the most of person-centred education by integrating flipped and simulated teaching: An exploratory study. Nurse education in practice, 27, 71-77. https:// doi.org/10.1016/j.nepr.2017.08.014

Schaufeli, W. B., Leiter, M. P., \& Maslach, C. (2009). Burnout: 35 years of research and practice. The Career Development International, 14(3), 204-220. https://doi.org/10.1108/13620430910966406

Shaliesh, K. (2018). Preventing and managing burnout: What we have learned? Biomedical Journal of Science and Technology Research, 2(1), 1-4.

Shirom, A. (2003). Job-Related Burnout: A Review. In J. C. Quick, \& L. E. Tetrick, (Eds.), Handbook of occupational health psychology (pp. 245-264). American psychological association. https://doi.org/10.1037/10474-012

Slavin, S. (2019). Preventing physician burnout: Satisfaction or something more?. Isr J Health Policy Res, 8(34), 1-3. https:/ / doi.org/10.1186/s13584-019-0303-y

Sokal, L., Eblie Trudel, L., \& Babb, J. (2020). How to prevent teacher burnout during the coronavirus pandemic. The Conversation. https://analytics.theconversation.com/ca/institutions/universityofWinnipeg3096/540/art icles/dates/20200516/20200616

Stoeber, J., \& Rennert, D. (2008). Perfectionism in school teachers: Relations with stress appraisals, coping styles, and burnout. Anxiety, stress, and coping, 21, 37-53. https://doi.org/10.1080/10615800701742461

UNESCO (2020b). COVID-19 educational disruption and response. UNESCO.

UNESCO. (2020a). Adverse effects of school closures. UNESCO. https://en.unesco.org/covid19/educationresponse/consequences

Veena, N., \& Shailaja, S. (2016). Stress and academic performance. International Journal of Indian Psychology, 3(4), 71-82

World Health Organization. (1948). Definition of health. http://www.who.int/about/definition/en/print.html

Young, M., Schieman, S., \& Milkie, M. A. (2013). Spouse's work-to-family conflict, family stressors and mental health among dual-earner mothers and fathers. Society and Mental Health, 4(1): 120.

Zhang, Q., \& Sapp, D. (2008). A burning issue in teaching: The impact of perceived teacher burnout and nonverbal immediacy on student motivation and affective learning. Journal of Communication Studies, 1(2), 152-168. 
Author (s):

* Mavis Osei (Corresponding Author)

Department of Educational Innovations in Science and Technology,

Kwame Nkrumah University of Science and Technology, Ghana

E-mail: adjakoma@yahoo.com

Dickson Adom

Department of Educational Innovations in Science and Technology,

Kwame Nkrumah University of Science and Technology, Ghana

E-mail: dickson.adom@knust.edu.gh/adomdick2@gmail.com

Ampofo Kwene

Department of Publishing Studies,

Kwame Nkrumah University of Science and Technology, Ghana

E-mail: ampofodrum@gmail.com

Nicholas Tetteh

Department of Industrial Art,

Dr. Hilla Limann Technical University, Ghana

E-mail: natdeconqueroracts635@gmail.com 